\title{
Response of Dividend Announcement on the Price of Mutual Fund: A Comprehensive Study on Mutual Fund Listed in Dhaka Stock Exchange (DSE)
}

\author{
Uttam Golder, Shahanaz Akter, Md. Imran Sheikh
}

Lecturer, Department of Finance and Banking, Faculty of Business Studies

Jashore University of science and Technology, Jashore- 7408

Lecturer, Department of Finance and Banking, Faculty of Business Studies

Jashore University of science and Technology, Jashore- 7408

Lecturer, Department of Management, Faculty of Business Studies

Jashore University of science and Technology, Jashore- 7408

\begin{abstract}
How dividend policy shakes the price of share of an enterprise' is one of the most significant research issues in the ground of modern investment and finance. This study examines the influence of dividend announcement on the price of the mutual fund those are registered in Dhaka Stock Exchange (DSE). The empirical part of this study uses "event study methodology" to know whether dividend announcement delivers any price sensitive information which creates a movement of the price of mutual funds. Although much studies are made on the topics of dividend policy, it is vague that whether dividend policy effects the stock price. The researcher who supports dividend irrelevance theory, argues that firm's value should depend on earning power of the company, not on in which way the total earnings are divided into dividend and retained earnings and at what amount dividend are given to the shareholder of the company. This research surveys price of mutual funds those are registered in Dhaka Stock Exchange (DSE) surrounding 44 days of the dividend announcement date. In this study, we examine 13 samples \& used event study technique that shows dividend announcement doesn't convey any price sensitive information immediately after announcement of dividend but price of the mutual fund goes to change dramatically before 7 days of record date which proves that announcement of dividend affects the price of mutual fund registered in Dhaka Stock Exchange (DSE). Finally, T-test also postulates that price of stock responses to dividend announcement is not statistically significant immediately from dividend announcement date to 7 days after the announcement date. However, an opposite result, the $\mathrm{T}$ test identifies that price of stock responses to the announcement of dividend is statistically significant from the 7 days before record date to record date.
\end{abstract}

Keywords: Dividend Policy, Capital Market, Mutual Fund, Cumulative Abnormal Return, Event Study, Market Price, Cash Dividend, Dhaka Stock Exchange.

\section{Introduction}

Capital market plays an imperative part to channel funds from surplus unit to deficit unit, as it helps to collect funds from those who poses a lot of money and also supports to transfer funds to the person who actually needs it. Fair, transparent and efficient capital market is crucial for collection of the funds and proper allocation of those resources for the economic development of the country. Financial manager of a company has to take three important decisions: investment, financing \& dividend decision. When an investor invests his fund in the capital market, considers some factors; for example, stock price, dividend, share index etc. Generally, companies provide dividend by means of cash or stock where every company tries to follow or maintain a pre-prescribed dividend policy that is set by its top level management. As, the main objective of a corporate entity is to maximize the wealth of the shareholders, company always tries to make decision in favor of its stockholders. From this view point, it declares dividend as a part of the income of the shareholder that is added to the capital gain and make the shareholder more profitable. However, 
Dividend strategy is essential for investors, mangers, lenders \& other stakeholder. If the dividend yield is low it signals either the corporation has good prospectus or it is in big trouble (Akhigbe, Stephen and Madura, 1993). Although dividend policy is one of the most significant researched issues, there is a debate whether the announcement of the dividend affects the price of mutual fund. There are two branches of concept about dividend policy: one is dividend relevance theory and another is dividend irrelevance theory. Both of the thoughts are trying to establish their own philosophy but none of them is free from its respective drawbacks.

Even though numerous studies have been accomplished on this area, there is quiet scope for the betterment of the theme. Most of the studies use event study method of Campbell and Wasley (1996) to determine abnormal stock price returns of stock which are included in event period are examined. However, if the stocks are treaded infrequently in the stock market, it creates upward and downward bias. Due to the form of market efficiency, standard event study methodology is pushed back from its actual objective. As a result, this study avoids abnormal return and consequently develop an alternative approach that is suitable to our market. The aim of this study is to reveal the influence of dividend announcement of the price of mutual fund registered in Dhaka Stock Exchange (DSE) which declared dividend in 2018. This study examines the influence of dividend announcement of the price of mutual fund through theoretical and empirical concept.

This study has some practical and theoretical implications. As, it tries to reveal the response of dividend announcement on the price of mutual fund listed on Dhaka Stock Exchange (DSE), it will be helpful for both individual and institutional investors who want to invest their funds in mutual fund. It will open a new scope for those who will want to study more about the nature and opportunity of mutual fund of Bangladesh in future.

\section{Theoretical Background}

Researchers have studied the question how dividend policy affects a firm's stock price for many years but they have not reached definite conclusion. Besley \& Brigham (2007) identified that there are two branches of ideas concerning dividend policy. One is dividend relevance and another is dividend irrelevance policy. Dividend irrelevant theory considers a firm's value should be determined by the basic earning influence and the business risk of the firm. Here the value depends on the income produce, not on in what way the income is fragmented in the middle of dividend and earnings. Conversely, in dividend relevance theory, the value of the firm is influenced by its dividend policy. Investors prefer to receive dividend today because current dividend payment are more certain that the future capital gains.

Walter (1963) contends that the value of the firm is always affected by the selection of dividend policy. A firm's dividend \& investment policy cannot be separated from one another. This dispute is based on the association between a firm's return on investment and its cost of funding that is used to determine the dividend policy where all the financing is done through retained earnings (debt or new equity is not issued), the firms internal rate of return and its cost of capital are considered constant, all the earnings are either give away as dividend or reinvested immediately, the life of the enterprise is perpetual and it will maximize the wealth of the shareholder.

Gordon (1963) opinions that a firm's value is influenced by its dividend policy. According to him the market price of a share is identical to the present value of future cash inflow regarded as dividend. ModiglianiMiller (1961) state that investment policy determines the worth of the firm. The fragmentation between dividend and funds that will be reinvested does not influence the value of the firm. Here it is assumed that market is perfectly competitive, no corporate or personal tax as well as transaction cost, and the investors behave rationally to maximize their wealth and no investor are capable to influence the securities price.

Signaling theory is deemed to be the information contents of dividends hypothesis. As stated by Besley and Brigham (2007), a larger than predictable dividend growth is treated by shareholders as a symbol that the management of the firm projects enhanced future incomes, while a dividend lessening hints a prediction of a smaller amount earnings. They claimed that shareholders' responses to alter in dividend disbursement do not present that investors like dividends than retained earnings; rather, the stock price changes simply indicate that important information is contained in dividend announcements. 
The different tax behavior of dividend and capital gains may influence the preference of the investor for dividend vs. capital gain. The investors who depend on regular and low income will chose those firm that pay high and constant dividend. However, the investors who are in high tax bracket may select to invest in that firm which hold most of their earnings to obtain prospective capital gain (Kinkki, 2001).

Investors may change their portfolio selection because of the transection cost. Small investors depend on dividend income to meet up their daily necessities and they may chose high and constant dividend stocks. Conversely, wealthy investor who don't rely on their share portfolios to meet up their daily necessities are attracted low payout ratio as they want to avoid the transaction cost and reinvest those (Al-Malkawi, Rafferty \& Pillai, 2010).

In corporate entities ownership is separated from controlling or management. It may encourage to abuse the company's asset for their own interest. If the manager provides regular dividend, it ensures that they are conscious for their own responsibility (Easterbrook, 1984).

\section{Empirical Review}

In financial world, there are several ideas concerning the association between the dividend policy and stock price. Black and Scholes (1974) strongly supports Modigliani-Miller's dividend irrelevance theory. They inspected the association between security return and dividend yield. According to their study there is no certain effect on the stock price if a company increases its dividend. Uddin \& Chowdhury (2005) also supported the M-M model of dividend irrelevance theory. They conducted an empirical analysis based on 137 sample of dividend paying company those are listed in DSE. They identified that shareholders do not gain value from dividend announcement and shareholders lost $20 \%$ of value over a period of 30 days prior to dividend announcement through to 30 days after the announcement.

Ahsan \& Bashar (1997) showed that there was no significant effect of dividend announcement on the stock price. They used 21 actively traded securities of DSE. They empirically showed dividend announcement does not convey positive information about the firm in Dhaka Stock Exchange. In an imperfect DSE, investor generally expects the market price of the security will decline by more than amount of dividend declared on the very first day of closing period. According to their statement capital market of Dhaka was in an infant level to access the data and information.

Comparison period research method was applied by Woolridge (1983) where he used 225 firms of NYSE from 1970 to 1977 and found that changes of dividend significantly impacts on share price. This study identified a positive return on stock by a rise in dividend and a negative return with a deduction in dividends supported by signaling theory. Another study conducted by Goldstein and Fuller (2003) reveled that in declining market condition investors prefer dividend disbursing stocks to non-dividend disbursing stocks. Using S\&P 500 monthly returns they identified that dividend disbursing firms generate higher returns than non-dividend disbursing firms which is also consistent with signaling theory of dividend. Gupta et al., (2012) concluded about the inefficiency of Indian stock market where he used event study methodology to examine the reaction of dividend announcement on stock value of 28 firms for the period of 2006-09 which were registered on BSE 30 Sensex. He also identified that most of the managers consider dividend announcement as an advantageous event for their company as it gives a positive signal about the goodwill and stock price of that particular company.

Ali \& Chowdhury (2010) empirically examined the stock price response to the announcement of dividend of the listed private commercial banks in Dhaka Stock Exchange (DSE). Their result ident ified that the reaction of the price of stock to dividend announcement is not statistically significant and dividend declaration does not provide any significant information. Rahman, Amin \& Siddikee (2012) conducted a research on the impact of various kinds of dividend announcement viz. stock and cash dividend by taking event study method, MAAR and CAR, their study identified no proof of abnormal returns on the day of announcement for either of the types of dividend. However, Mamun, Hoque \& Mamun (2013) lead a research on the stock price responses to dividend announcement. They concluded that the announcement of dividend does not carry any advantage to the investors. Moreover they lose for considerable fall in share price.

Capital Asset Pricing Model (CAPM) was used by Raja, Sangani \& Joshi, (2015); in their study Judgmental sampling of Bombay Stock Exchange (BSE) with Paired T Test and Wilcoxon Signed Ranks test were 
applied to know the relationship between stock price movement and dividend announcement. This study revealed that in short term, share price may be manipulated and price of shares are affected by announcement of dividend but in long term the announcement of dividend does not shake the price of share evidenced by Modigliani and Miller, (1961).

Rahman \& Rahman (2008), in their study found an increase of share price around ex-dividend date from Dhaka Stock Exchange (DSE). They commented that ex-dividend price increased instead of decreasing in Dhaka Stock Exchange (DSE). The findings of Abbas (2014) shows that there is no leakage of information prior to announcement of dividend. As a result, significant abnormal returns before the dividend announcement date is also absent. This study also concluded that the adjustment of stock price starts six days after the dividend announcement date and lasts at least fifteen days. In the meantime (post event windows) dividend information is used by the investors to get abnormal return.

\section{Methodology \& Data Sources}

In order to examine the response of dividend announcement on the price of mutual fund we have analyzed stock price of selected mutual fund surrounding 44 days of the date of dividend announcement of Dhaka Stock Exchange (DSE).

\subsection{Hypothesis to be tested}

In this study we have selected our null hypothesis is that there is no significant impact of dividend announcement on mutual fund price movement. So,

$H_{o}$ : Dividend announcement doesn't convey any price sensitive information.

$H_{A}$ : Dividend announcement conveys price sensitive information.

\subsection{Sample Period}

To examine the influence of dividend announcement on the price of the selected mutual fund of DSE, we have taken our sample period from $1^{\text {st }}$ January 2018 to $31^{\text {st }}$ December 2018 . This study mainly focuses on the date of dividend announcement and record date. It uses daily information of the securities and the mutual fund index of DSE. This study also considers different types of secondary data that are collected from Dhaka stock Exchange library, different types of Dhaka Stock Exchange (DSE) publication and the website of DSE.

\subsection{Population and Sample}

During our sample period we have found 32 mutual funds those were listed at Dhaka Stock Exchange (DSE). At the preliminary stage this study selected all the mutual funds. After that we have refined our sample size and at the second stage we have selected 13 mutual funds. Our study excluded 19 mutual funds those couldn't satisfy the research requirement. We have selected mutual funds on the basis of three requirements: I) the mutual fund that declared its dividend 30 days after $1^{\text {st }}$ January 2018 , II) the mutual fund that announced its record date within $31^{\text {st }}$ December 2018 and III) the mutual fund that has a minimum gap of 14 days of regular transaction between dividend announcement date and record date. The mutual funds which satisfied our all three requirements are DBH First Mutual Fund, SEML Lecture Equity Management Fund, "Reliance One" the first scheme of Reliance Insurance Mutual Fund, AB Bank 1st Mutual Fund, EBL NRB Mutual Fund, Popular Life First Mutual Fund, PHP First Mutual Fund, 1st Janata Bank Mutual Fund, First Bangladesh Fixed Income Fund, EBL First Mutual Fund, IFIC Bank 1st Mutual Fund, EXIM Bank 1st Mutual Fund and Trust Bank First Mutual Fund.

\subsection{Event Window}

It is important to identify the time frame over which the relevant data will be evaluated. This period is known as 'event window' (Campbell, Lo and Mackinley, 2012). In this study our event window is equal to 44 days that start from 30 days before the dividend announcement date and ends 14 days after the dividend announcement date (Figure:1). To simplify our analysis we have set dividend announcement date as $t=0$. Primarily event window is divided into two categories I) Pre-event window: 30 days before $t=0$ (dividend announcement date), II) Post event window: 14 days after $t=0$ (dividend announcement date). Again post event window is segmented into two parts, a) price adjustment period $(+1$ days to +7 days price impact after 
dividend announcement date), b) market response to the period of availing dividend benefit ( +1 days to +7 days price impact before record date).

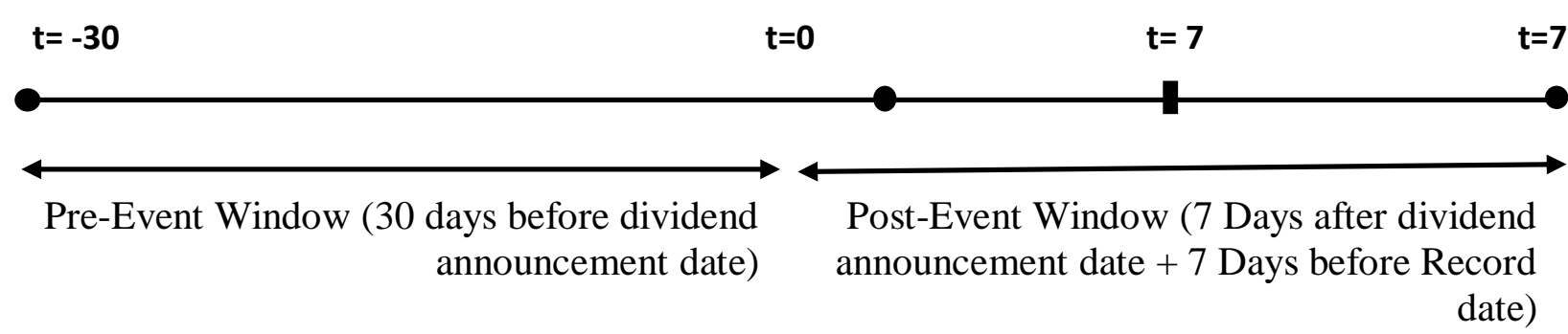

\section{Figure 1: Pre-event and Post-event Window}

\subsection{Event Study method}

Event study methodology attempts to measure the outcome of an unanticipated economic event (Mackinlay, 1997). This method is useful for empirical study as security price of the firm may response immediately to an event which has an impact on firm's current and future earnings. It observes abnormal returns of the stock's price. Abnormal returns can be termed as the variance between actual return and expected return that is denoted as $\mathrm{AR}_{\mathrm{it}}$.

$$
A R_{i t}=R_{i t}-E\left(R_{i t}\right)
$$

Abnormal return and cumulative abnormal return of pre and post event window are calculated to know the impact of the event. The daily equity price return of the relevant company $\left(R_{i t}\right)$ is regressed over the respective industry index $\left(\mathrm{R}_{\mathrm{mt}}\right)$ to calculate the value of abnormal return that is as follows:

$$
R_{i t}=\alpha_{i}+\beta_{i} R_{m t}
$$

Coefficient of determination $\left(\mathrm{R}^{2}\right)$ measures the power of this model as it determines the affiliation between two variables. It is identified that $\mathrm{R}^{2}$ is very low in most of the situations. Both frequently and infrequently traded data are used to determine the index. But frequently and infrequently traded data creates upward and downward bias respectively. So we have avoided this model and developed an alternative approach which avoids regression model but reflects the behavior of industry index.

\subsection{Alternative Approach: Market Adjusted Returns}

After deducting 19 samples those don't satisfy our requirement, we get 13 samples. To test the hypothesis we have used mean price of event period. We have also proved it graphically by market adjusted equity price of 13 samples. For pre event window market adjusted price of an equity $(i)$ for a day $(t)$ is calculated as:

$$
\text { Adj } R_{i t}=\frac{R_{i t}}{100+30 \text { Days Av. Industry Index Growth }} \times 100
$$

For post event window (both 7 days after dividend announcement date and 7 days before record date) market adjusted price of an equity $(i)$ for a day $(t)$ is calculated as:

$$
\operatorname{Adj} R_{i t}=\frac{R_{i t}}{100+7 \text { Days Av. Industry Index Growth }} \times 100
$$

To make the conclusion we will observe the daily market adjusted return for both pre event and post event window.

\subsection{Testing Hypothesis}

In this study, null hypothesis $\left(H_{0}\right)$ is dividend announcement doesn't convey any price sensitive information that means dividend announcement doesn't significantly impact on the stock price of our selected mutual funds and our alternative hypothesis $\left(H_{A}\right)$ is dividend announcement conveys price sensitive information. In 
both of the two windows we have assumed the prices of the mutual fund are normally distributed and they are independent. T- Test has been conducted as 95\% confidence level to test our hypothesis.

\section{Empirical Results}

The analysis of the reaction of dividend announcement on the price of 13 selected mutual funds shows insignificant impact on the price movement of mutual funds immediately after the announcement of dividend and continues till the 7 days after the announcement of dividend. We have found tk. 49.35 as the adjusted mean return index of stocks 30 days before dividend announcement date. Conversely, tk. 51.95 as the adjusted mean return index in price adjusted period and tk. 44.80 as the adjusted mean return index 7 days before the record date. So in price adjustment period the stock price is increased by $5.27 \%$ which proves that the announcement of dividend has a low impact on the prices of the mutual fund. However, the price of mutual fund is decreased by $9.22 \%$ in the time of availing the dividend benefit ( 7 days before record date) which supports that dividend announcement contains piece sensitive information. Table: 1 and 2 show the list of mean return and standard deviation of 13 mutual funds during 30 days before dividend announcement date, 7 days after dividend announcement date and 7 days before record date. The result is also shown on Figure: 2.

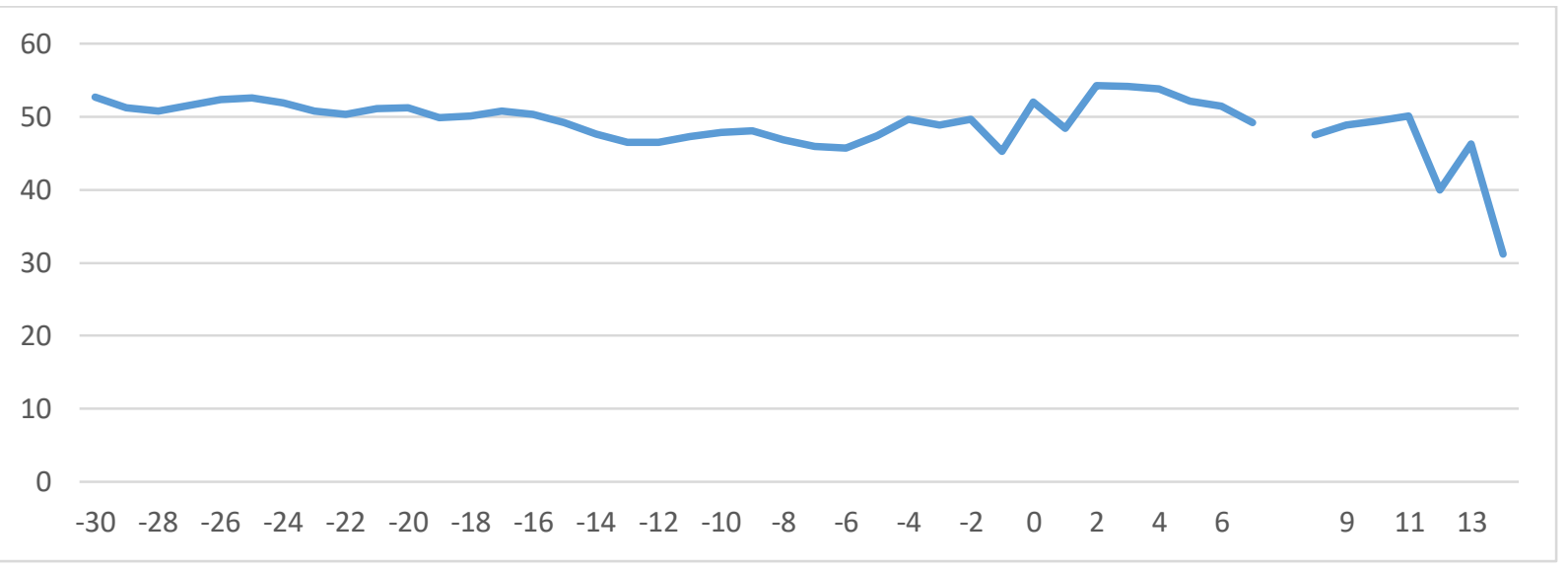

Figure 2: Adjusted Stock Prices in the Time Frame

Table 1: Mean and Standard Deviation of Pre-Event and Post-Event Window

\begin{tabular}{|c|c|c|c|c|c|c|c|}
\hline \multirow{2}{*}{$\begin{array}{l}\text { Sl } \\
\text { No. }\end{array}$} & \multirow{2}{*}{ Name of the Banks } & \multicolumn{3}{|c|}{$\begin{array}{l}\text { Pre-event Window (30 Days Before } \\
\text { Dividend Announcement Date) }\end{array}$} & \multicolumn{3}{|c|}{$\begin{array}{l}\text { Post-event Window (7 Days After } \\
\text { Dividend Announcement Date) }\end{array}$} \\
\hline & & $\mathbf{N}$ & Mean & $\begin{array}{c}\text { Std. } \\
\text { Deviation }\end{array}$ & $\mathbf{N}$ & Mean & $\begin{array}{c}\text { Std. } \\
\text { Deviation }\end{array}$ \\
\hline 1 & DBH First Mutual Fund & 30 & 49.33 & 2.54 & 7 & 48.80 & 3.79 \\
\hline 2 & $\begin{array}{l}\text { SEML Lecture Equity Management } \\
\text { Fund }\end{array}$ & 30 & 49.29 & 2.42 & 7 & 49.34 & 1.57 \\
\hline 3 & $\begin{array}{l}\text { "Reliance One" the first scheme of } \\
\text { Reliance Insurance Mutual Fund }\end{array}$ & 30 & 50.12 & 2.78 & 7 & 48.67 & 4.06 \\
\hline 4 & AB Bank 1st Mutual Fund & 30 & 49.09 & 2.78 & 7 & 88.51 & 18.52 \\
\hline 5 & EBL NRB Mutual Fund & 30 & 49.40 & 2.43 & 7 & 49.34 & 1.57 \\
\hline 6 & Popular Life First Mutual Fund & 30 & 49.25 & 2.87 & 7 & 48.74 & 2.78 \\
\hline 7 & PHP First Mutual Fund & 30 & 49.09 & 2.78 & 7 & 48.74 & 2.78 \\
\hline 8 & 1st Janata Bank Mutual Fund & 30 & 49.09 & 2.78 & 7 & 48.74 & 2.78 \\
\hline 9 & $\begin{array}{l}\text { First Bangladesh Fixed Income } \\
\text { Fund }\end{array}$ & 30 & 49.09 & 2.78 & 7 & 48.30 & 2.75 \\
\hline 10 & EBL First Mutual Fund & 30 & 49.40 & 2.43 & 7 & 49.34 & 1.57 \\
\hline 11 & IFIC Bank 1st Mutual Fund & 30 & 49.40 & 2.43 & 7 & 49.34 & 1.57 \\
\hline 12 & EXIM Bank 1st Mutual Fund & 30 & 49.94 & 2.88 & 7 & 48.83 & 3.90 \\
\hline 13 & Trust Bank First Mutual Fund & 30 & 49.09 & 2.78 & 7 & 48.74 & 2.78 \\
\hline
\end{tabular}


Table 2: Mean and Standard Deviation of Pre-Event and Post-Event Window

\begin{tabular}{|c|c|c|c|c|c|c|c|}
\hline \multirow{2}{*}{$\begin{array}{l}\text { Sl } \\
\text { No. }\end{array}$} & \multirow[t]{2}{*}{ Name of the Banks } & \multicolumn{3}{|c|}{$\begin{array}{l}\text { Pre-event Window (30 Days before } \\
\text { Dividend Announcement Date) }\end{array}$} & \multicolumn{3}{|c|}{$\begin{array}{c}\text { Post-event Window (7 days Before } \\
\text { Record Date) }\end{array}$} \\
\hline & & $\mathbf{N}$ & Mean & $\begin{array}{c}\text { Std. } \\
\text { Deviation }\end{array}$ & $\mathbf{N}$ & Mean & $\begin{array}{c}\text { Std. } \\
\text { Deviation }\end{array}$ \\
\hline 1 & DBH First Mutual Fund & 30 & 49.33 & 2.54 & 7 & 42.23 & 3.21 \\
\hline 2 & $\begin{array}{l}\text { SEML Lecture Equity Management } \\
\text { Fund }\end{array}$ & 30 & 49.29 & 2.42 & 7 & 46.29 & 4.85 \\
\hline 3 & $\begin{array}{l}\text { "Reliance One" the first scheme of } \\
\text { Reliance Insurance Mutual Fund }\end{array}$ & 30 & 50.12 & 2.78 & 7 & 48.74 & 2.78 \\
\hline 4 & AB Bank 1st Mutual Fund & 30 & 49.09 & 2.78 & 7 & 46.29 & 4.85 \\
\hline 5 & EBL NRB Mutual Fund & 30 & 49.40 & 2.43 & 7 & 46.29 & 4.85 \\
\hline 6 & Popular Life First Mutual Fund & 30 & 49.25 & 2.87 & 7 & 46.29 & 4.85 \\
\hline 7 & PHP First Mutual Fund & 30 & 49.09 & 2.78 & 7 & 46.29 & 4.85 \\
\hline 8 & 1st Janata Bank Mutual Fund & 30 & 49.09 & 2.78 & 7 & 46.29 & 4.85 \\
\hline 9 & $\begin{array}{l}\text { First Bangladesh Fixed Income } \\
\text { Fund }\end{array}$ & 30 & 49.09 & 2.78 & 7 & 46.29 & 4.85 \\
\hline 10 & EBL First Mutual Fund & 30 & 49.40 & 2.43 & 7 & 46.29 & 4.85 \\
\hline 11 & IFIC Bank 1st Mutual Fund & 30 & 49.40 & 2.43 & 7 & 46.29 & 4.85 \\
\hline 12 & EXIM Bank 1st Mutual Fund & 30 & 49.94 & 2.88 & 7 & 48.67 & 2.82 \\
\hline 13 & Trust Bank First Mutual Fund & 30 & 49.09 & 2.78 & 7 & 46.29 & 4.85 \\
\hline
\end{tabular}

The graphs in Figure: 3 disclose different results in response to announcement of dividend of different mutual funds. Price of most of the mutual funds tends to a slight increase with the announcement of dividend but a significant fall down before 7 days of record date. So this study, on an average, finds no significant impact on the price of the mutual funds from event date (dividend announcement) to 7 days after dividend announcement date. However, the announcement of dividend, on an average finds a significant impact on the price of the mutual fund before 7 days of record date.
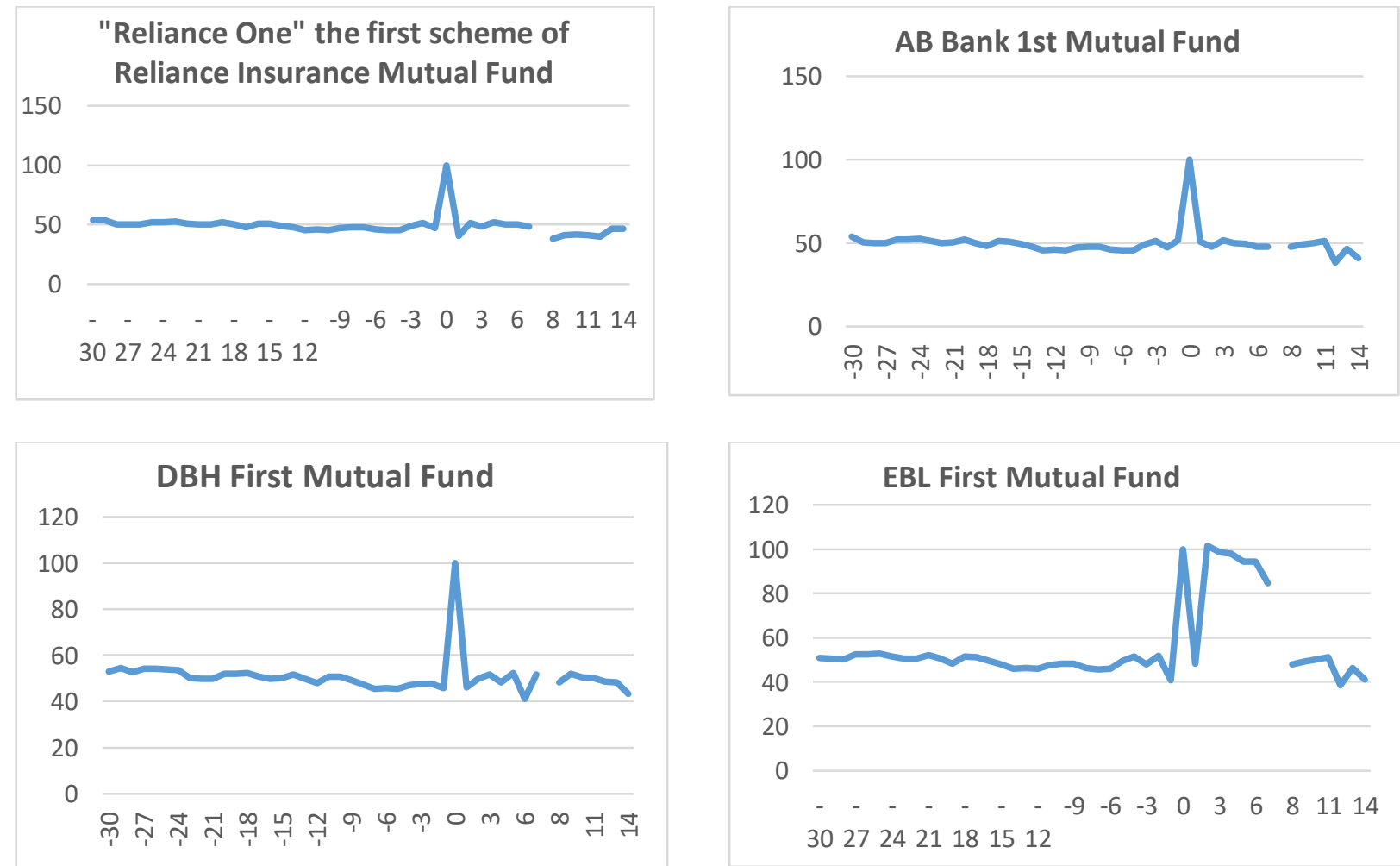

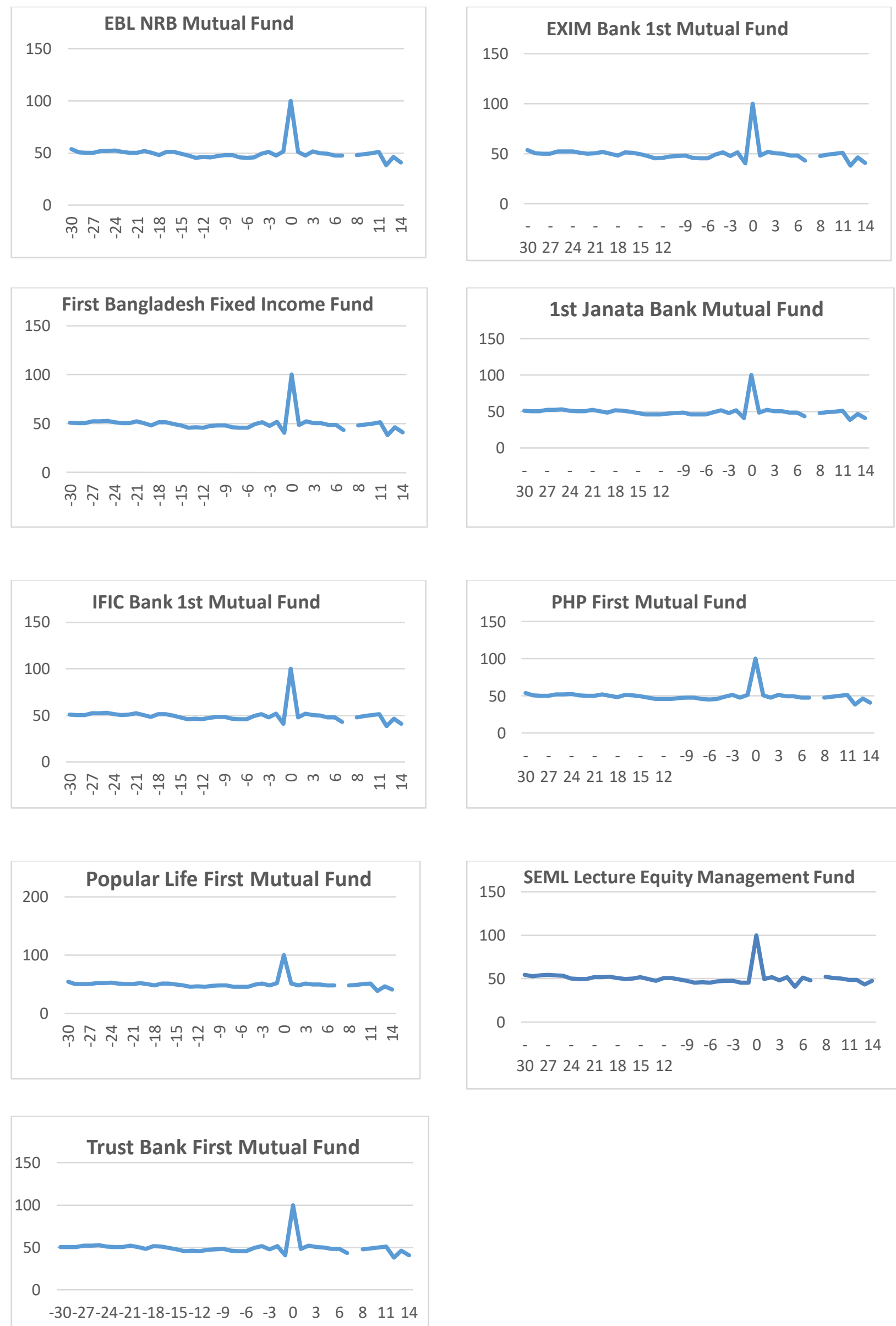

Figure 3: Stock Price Movements of Mutual Funds around the Date of Dividend Announcement (Price of the event day is considered as tk. 100 and the same is adjusted with the pre-event and post-event window) 
Table 3: Hypothesis test: Independent Groups (t-test, pooled variance) (30 Days before Dividend Announcement Date \& 7 days after Dividend Announcement Date)

\begin{tabular}{|l|r|r|}
\hline & \multicolumn{1}{|c|}{ Mean } & Mean \\
\hline Mean & 49.35463022 & 51.95425585 \\
\hline Variance & 0.10800275 & 120.7242012 \\
\hline Observations & 13 & 13 \\
\hline Hypothesized Mean Difference & 12 & \\
\hline Df & -0.852689935 & \\
\hline $\mathrm{t}$ Stat & 0.205263823 & \\
\hline $\mathrm{P}(\mathrm{T}<=\mathrm{t})$ one-tail & 1.782287556 & \\
\hline $\mathrm{t}$ Critical one-tail & 0.410527646 & \\
\hline $\mathrm{P}(\mathrm{T}<=\mathrm{t})$ two-tail & 2.17881283 & \\
\hline $\mathrm{t}$ Critical two-tail & \multicolumn{2}{|l|}{} \\
\hline
\end{tabular}

Table: 4 Hypothesis test: Independent Groups ( $t$-test, pooled variance) (30 Days before Dividend Announcement Date \& 7 days Before Record Date)

\begin{tabular}{|l|r|r|}
\hline & \multicolumn{1}{|c|}{ Mean } & \multicolumn{1}{|c|}{ Mean } \\
\hline Mean & 49.35463022 & 46.34781644 \\
\hline Variance & 0.10800275 & 2.344305362 \\
\hline Observations & 13 & 13 \\
\hline Hypothesized Mean Difference & 0 & \\
\hline Df & 13 & \\
\hline t Stat & 6.922941971 & \\
\hline P(T<=t) one-tail & $5.24209 \mathrm{E}-06$ & \\
\hline t Critical one-tail & 1.770933396 & \\
\hline $\mathrm{P}(\mathrm{T}<=\mathrm{t})$ two-tail & $1.04842 \mathrm{E}-05$ & \\
\hline $\mathrm{t}$ Critical two-tail & 2.160368656 & \\
\hline
\end{tabular}

Results of table 3 identify that there is no significant association between dividend announcement and the price movement of mutual funds from event date (dividend announcement date) to 7 days after dividend announcement date as the $P$ value is greater than 5\% level of significance in parametric pooled $t$-test which fails to reject null hypothesis and thus confirms that dividend announcement doesn't convey any price sensitive information. However, our analysis in table 4 also shows that the value of $p$ is less than 5\% which allows to reject null hypothesis and approves that announcement of dividend conveys significant price sensitive information and price of mutual is affected from 7 days before record date.

\section{Conclusion}

The stock exchange of Bangladesh experienced a significant ups and downs in the last 16 years. The world economic crisis 2009-2011 affected the economy of Bangladesh. So this factor also affected our analysis. The stock market of Bangladesh is still in immature form and it is in speculation and manipulation stage. The level of literacy of our individual investors is very low and to some extent they do not know how to operate their account and most often they take help from their friends and relatives and take the wrong decision. The investors often follow the insiders to take their investment decision as the insiders know private information and the investors are misled because of private information. The objective of this study is to revel response of dividend announcement on the Price of Mutual Funds those are registered in Dhaka Stock Exchange and our result shows that dividend announcement doesn't convey any price sensitive information immediately after announcement of dividend but price of the mutual funds go down dramatically before 7 days of record date which proves that announcement of dividend affects the price of mutual fund. The probable reason behind it is the nature and prospectus of mutual fund of Bangladesh. 
Some asset management companies of Bangladesh declared a reduced amount of dividend for their mutual funds and others declared exactly same percentage of dividend compared to the preceding year. It may provide some negative signals about the prospectus of mutual fund to the investors as it can indicate a cash flow problem and it may be the result of unfavorable business conditions; for example increasing of expanse and decreasing profit which may reluctant the investors to hold their mutual funds and subsequently fall in the price of it.

\section{Reference}

[1] Abbas, G. (2014), 'Testing Random Walk Behavior in the Damascus Securities Exchange', International Journal of Academic Research in Accounting, Finance, Vol. 4, No. 4.

[2] Ahsan, A. and Bashar, O. M. 'Security Price Reaction to Dividend Announcement: Evidence from Dhaka Stock Exchange Ltd', Bangladesh Online Research Network, http://Www.Bdresearch.Org.Bd

[3] Akhigbe, Aigbe and Borde, Stephen F. and Madura, Jeff, (1993), 'Dividend Policy and Signaling by Insurance Companies', Journal of Risk and Insurance, Vol. 60, No. 3. Available at SSRN: https://ssrn.com/abstract=153108

[4] Al-Malkawi, H.N, Rafferty, M. and Pillai, R. (2010), 'Dividend Policy: A Review of Theories and Empirical Evidence', International Bulletin of Business Administration, 171-200.

[5] Bayezid, A. and Chowdhury, A. (2010), 'Effect of Dividend on Stock Price in Emerging Stock Market: A Study on the Listed Private Commercial Banks in DSE', International Journal of Economics and Finance, Vol. 2, No. 4.

[6] Besley, S. and Brigham, E. F. (2007), "Essentials of Managerial Finance". $14^{\text {th }}$ edn. United States of America: Thomson South-Western.

[7] Black, F. and M. S. Scholes, (1974), 'The Effect of Dividend Yield and Dividend Policy on Common Stock Prices and Return', Journal of Financial Economics, Vol. 1, pp. 1-22.

[8] Campbell, C. and Wasley, C. (1996), 'Measuring abnormal trading volume for samples of NYSE/ASE and NASDAQ securities using parametric and nonparametric test statistics', Review of Quantitative Finance and Accounting.

[9] Campbell, J. Y., Lo, A. W. and MacKinlay, A. C. (2012), 'The Econometrics of Financial Markets', Princeton University Press, New Jersey.

[10] Easterbook, F. H. (1984), 'Two Agency-cost Explanations of Dividends', American Economic Review. Vol. 74, No. 4, pp. 650-659.

[11] Goldstein, M. A. and Fuller, K. P. (2003), 'Dividend Policy and Market Movements', Working Paper, University of Mississippi - School of Business Administration.

[12] Gordon, M. J. (1963), 'Optimum Investment and Financing Policy', Journal of Finance, 18, 264-272.

[13] Gupta, S., Dogra, B., Vashisht A. K. and Ghai S. (2012), 'Stock Price Reaction to Dividend Announcements', International Journal of Financial Management; New Delhi, Vol. 2, pp. 23-31.

[14] Kinkki, S. (2001), 'Dividend puzzle-a review of dividend theories', Liiketaloudellinen aikakauskirja, pp. 58-97.

[15] Mackinlay, A. C. (1997), 'Event Studies in Economics and Finance', Journal of Economic Literature, Finance" Vol. 35, pp.13-39

[16] Mamun, A. Hoque, N. and Mamun, A. M. A. (2013), 'Stock Price Reaction to dividend announcement: the case of Bangladesh Capital market', Journal of Economics and Sustainable Development, Vol.4, No. 8, pp. 89-98.

[17] Miller, M. H. and Modigliani, M. (1961), 'Dividend Policy, Growth and the Valuation of Shares', Journal of Business, 34, 411-433.

[18] Raja, A. Sangani, J. and Joshi, K. (2015), 'Dividend Announcement and Stock Price Behavior: Indian Evidences'

[19] Rahman, Amin and Siddikee (2012), 'Announcement Effect of Cash \& Stock Dividends on Share Price: An Empirical Study on Dhaka Stock Exchange', Asian Business Review, Vol. 1, No. 1.

[20] Rahman, Z. and Rahman, L. (2008), 'Stock Price Behavior Around of Ex-dividend Day: Evidence from Dhaka stock Exchange', Journal of Business Administration, Vol. 34, pp. 127-144.

[21] Uddin M.H and Chowdhury G. M (2005), 'Effect of Dividend Announcement on Shareholders' Value: Evidence from Dhaka Stock Exchange’, Journal of Business Research, Vol. 1 
[22] Walter, J. E., (1963), 'Dividend Policy: It's Influence on the Value of Enterprise', Journal of Finance, Vol. 18, pp. 280-291.

[23] Woolridge, J. R. (1983), 'Dividend Changes and Security Prices', Journal of Finance, Vol. 38, No. 5, pp. 1607-1615. 